\title{
Electrochemical performance of different carbon fuels on a hybrid direct carbon fuel cell
}

\author{
Shuangbin $1^{1,2}$, Wenzhi Pan $^{1}$, Shaorong Wang ${ }^{3, *}$, Xie Meng $^{1}$, Cairong Jiang ${ }^{2}$, and \\ John T. S. Irvine ${ }^{2}$ \\ 1 CAS Key Laboratory of Materials for Energy Conversion, Shanghai Institute of Ceramics, \\ Chinese Academy of Sciences (SICCAS) \\ 2 School of Chemistry, University of St Andrews, KY16 9ST, United Kingdom \\ 3 School of Chemical Engineering \& Technology, China University of mining and Technology
}

\begin{abstract}
Recently hybrid direct carbon fuel cells (HDCFC) has attracted great attention, combining the advantages of solid oxide fuel cells and molten carbonate fuel cells, to convert energy of carbon to electricity directly without chemical combustion. In this work, three processed carbon fuels including activated carbon, carbon black and graphite have been employed to investigate influence of the chemical and physical properties of carbon on the HDCFC performance in different anode atmospheres at $650-800{ }^{\circ} \mathrm{C}$. The results reveal that the electrochemical activity is strongly dependent on crystalline structure, thermal stability and textural properties of carbon fuels. The activated carbon samples demonstrate a better performance with a peak power density of $326 \mathrm{~mW} \mathrm{~cm}^{-2}$ in $\mathrm{CO}_{2}$ at $750{ }^{\circ} \mathrm{C}$, compared to 147 and $59 \mathrm{~mW} \mathrm{~cm} \mathrm{~cm}^{-2}$ with carbon black and graphite samples, respectively. The impedance spectra indicates the polarization resistance plays a more dominated role in the cell performance. When replacing $\mathrm{N}_{2}$ by $\mathrm{CO}_{2}$ purge gas, the power density is the strongly temperature dependent due to the Boudouard reaction.
\end{abstract}

Keywords: Hybrid direct carbon fuel cell (HDCFC); Carbon fuels; Electrochemical performance 


\section{Introduction}

Coal is the most abundant fossil fuel and broadly distributed around the world. It is well known that conventional coal-fired power plants have a low efficiency and high pollution emission. The direct carbon fuel cells (DCFC) are promising alternative devices which electrochemically convert the chemical energy of solid carbon fuels into electrical energy with a high conversion efficiency [1-3]. The solid carbon fuels feeding to the DCFC is easily available from various sources, including petroleum, natural gas, coal, biomass (wood, rice straw, corn stover) and organic waste[4]. Compared to other fuel cells utilizing gaseous and liquid feedstocks, the DCFC has the intrinsic advantage of an almost $100 \%$ thermodynamic efficiency due to positive entropy change at high temperature.

Since Jacques[5] designed the first DCFC configuration in the 19th century, many DCFC concepts have been proposed to convert carbonaceous feedstocks into electricity, such as molten hydroxide (MHFC)[6, 7], molten carbonate (MCFC)[8], solid oxide (SOFC) $[9,10]$ and more attractive hybrid direct carbon fuel cells (HDCFC) combining characteristics of the MCFC and SOFC technology[11]. In this HDCFC configuration the stoichiometric mixture of solid carbon and molten carbonate works as an extended region in the SOFC anode compartment, and cathode provides the oxygen ions that migrate through a solid oxide electrolyte to react with the solid carbon to produce electricity. This liquid/solid interface seems to provide a very attractive way to resolve solid/solid contact problems and avoid $\mathrm{CO}_{2}$ circulation[12].

Jiang et al.[13] successfully demonstrated the feasibility of the raw coals, including 
anthracite, bituminous and lignite applied on HDCFCs. The key parameters for promising performance are high carbon content, low ash and sulphur content. They also concluded that the carbon monoxide concentration is highly dependent on the ratio of oxygen to carbon.

Xu et al.[14, 15] evaluated the performance of various carbon fuels employing YSZ and SDC electrolyte. The results showed that among three types of carbon fuels the electrochemical reactivity was in the order of activated carbon $>$ German creek coal > graphite. Activated carbon achieved a higher peak power density of $158.3 \mathrm{mWcm}^{-2}$ at $750{ }^{\circ} \mathrm{C}$ with YSZ electrolyte and $113.1 \mathrm{mWcm}^{-2}$ with GDC electrolyte at $650{ }^{\circ} \mathrm{C}$.

The cell performance of treated anthracite and bituminous coals, as well as carbon black were tested in mixed $\mathrm{N}_{2}-\mathrm{CO}_{2}$ between 700 and $800{ }^{\circ} \mathrm{C}$ by Deleebeeck et al.[16] . Electrochemical testing revealed that Bituminous coal showed the highest activity, likely associated to a high $\mathrm{O} / \mathrm{C}$ ratio and hydrogen content. As the concentration of $\mathrm{CO}_{2}$ was increased, the bubble formation increased in the anode chamber and the current density decreased.

There has many attempts to investigate electrochemical properties of various carbon fuels in different DCFC configurations. The carbon with more edge sites, defects, disordered structure and oxygen-containing groups has been proved to contribute to higher electrochemical activity in solo DCFC configuration. Whereas, the hybrid DCFC integration of molten carbonate and solid oxide based fuel cell is at the early stage in the field of DCFC. Even though the interest in HDCFCs, as well as publications, has risen, the detailed works should be emphasized on the effect of 
physical and chemical properties of carbon fuels on the electrochemical reactivity of carbon fuels in the anode reaction. In this work, three carbon samples were characterized in details for particle size (particle size distribution and scanning electron microscope), surface areas $\left(\mathrm{N}_{2}\right.$ adsorption experiments), graphitization (X-ray diffraction) and oxidation reactivity (thermo-gravimetric analysis). Furthermore, electrochemical performance of our prepared fuel cells was investigated using currentpotential- power density curves (I-V-P) and electrochemical impedance spectroscopy (EIS).

\section{Experimental}

\subsection{Characterization of carbon fuels}

Three types of commercial carbon were used in this study, containing ground granular activated carbon without sieving, carbon black, and graphite, which were referred to $\mathrm{AC}, \mathrm{BC}$ and $\mathrm{GC}$, respectively. A mixture of carbon and lithium-potassium carbonate $\left(62 \mathrm{~mol} \% \mathrm{Li}_{2} \mathrm{CO}_{3}-38 \mathrm{~mol} \% \mathrm{~K}_{2} \mathrm{CO}_{3}\right)$ in a mole ratio of $\mathrm{C}: \mathrm{CO}_{3}{ }^{2-}=4: 1$ was filled into the anode chamber and the amount of carbon-carbonate mixture was approximately $2 \mathrm{~g}$.

$\mathrm{N}_{2}$ adsorption isotherm experiments were performed using a Micromeritics TriStar II at $77.3 \mathrm{~K}$. Prior to the measurements, three carbon samples should be degassed at $150{ }^{\circ} \mathrm{C}$ for $12 \mathrm{~h}$ in the degas port. The $\mathrm{N}_{2}$ adsorption isotherms for different carbon fuels were obtained by the Barrett-Joyner-Hallenda (BJH) method with internal software. Further, the multiple-point Brunauer-Emmett-Teller (BET) calculation in the relative pressure range $\mathrm{P} / \mathrm{P}_{0}=0.05-0.30$ was carried out. 
Thermo-gravimetric analysis (TGA) was carried out with a Netzsch-209 apparatus with a heating rate of $5{ }^{\circ} \mathrm{C} \mathrm{min}{ }^{-1}$ under $\mathrm{N}_{2}$ and air flowing gas from room temperature to $900{ }^{\circ} \mathrm{C}$.

The crystallite parameters of three carbon samples were characterized by a PANalytical X-ray diffraction ( $45 \mathrm{kV}, 40 \mathrm{~mA}$ ) using a $\mathrm{Cu} \mathrm{K} \alpha$ radiation in the scanning $2 \theta$ range of $10-80^{\circ}$. The Particle Size Distribution of samples were carried out in water dispersant by Mastersize 2000 (Malvern). JSM-5600 (Jeol, Japan) scanning electron microscope (SEM) was employed to determine the morphology of the carbon fuels before and after electrochemical measurement.

2.2 Cell Fabrication, design and electrochemical measurement

Anode-supported SOFC were fabricated using several procedures. The porous $\mathrm{Ni} / \mathrm{YSZ}$ backbones (NiO/YSZ=60:40 wt\%), active Ni/YSZ active anodes and dense YSZ electrolytes were produced by laminating tape cast green tapes, followed by a cosintering process conducted at $1400{ }^{\circ} \mathrm{C}$ for $4 \mathrm{~h}$ in air. The button cells were cut into $2.5 \mathrm{~cm}$ in diameter by laser cutting machine directly from one large planar cell so that the anode and electrolyte layers of all cells were fabricated in the same condition. The GDC blocking layer was dip-coated on the YSZ electrolyte, which was sintered at $1200{ }^{\circ} \mathrm{C}$ for $2 \mathrm{~h}$, in order to prevent the insulating impurities appearing between the YSZ electrolyte and the GDC/LSGF composite cathode. After that, the GDC/LSGF composite cathode $(\mathrm{GDC} / \mathrm{LSCF}=50: 50 \mathrm{wt} \%)$ was screen printed on the surface of the thin GDC layer with $1.1 \mathrm{~cm}$ in diameter, and then the cathode was screen printed by LSCF slurry as current collection layer, co-calcining at $1050{ }^{\circ} \mathrm{C}$ for $4 \mathrm{~h}$. 
The schematic diagram of the HDCFC is presented in Fig. 1. For electrochemical measurements, silver grids were attached on each anode and cathode with silver wires as the voltage and current leads. The button cell was sealed onto the end of the alumina tube using ceramic pastes (Aremco 668) and the other side of tube was mounted with the Swagelok fitting to control inlet gas and outlet gas. The prepared apparatus was placed in the middle of the furnace with a type $\mathrm{K}$ thermocouple placed at the side of the fuel cell closely. During the heating stage, the $\mathrm{N}_{2}$ was purged into the anode compartment with a flow rate of $10 \mathrm{ml} / \mathrm{min}$ as the protected atmosphere. When the operating temperature was steady, the carrier gas $\left(\mathrm{H}_{2}, \mathrm{~N}_{2}\right.$, or $\left.\mathrm{CO}_{2}\right)$ was increased to 40 $\mathrm{ml} / \mathrm{min}$, while the cathode was ambient air. The current-voltage curves were measured by starting at an OCV and sweeping down to $0 \mathrm{~V}$ at a scanning rate of $20 \mathrm{mV} \mathrm{s}^{-1}$ at the temperature range of $650-800{ }^{\circ} \mathrm{C}$ using an IM6 Electrochemical Workstation (ZAHNER, Germany) with Thales Z2.12 USB software package. Electrochemical impedance spectroscopy was scanned from $100 \mathrm{kHz}$ to $0.1 \mathrm{~Hz}$ with an amplitude of 20 $\mathrm{mV}$. 


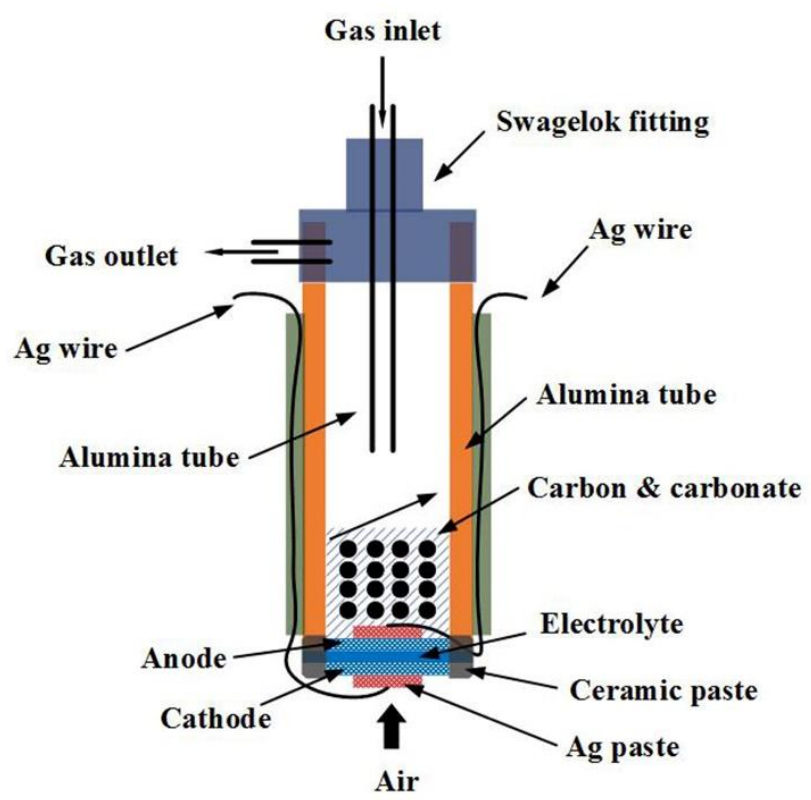

Fig. 1. Schematic diagram of the HDCFC cell.

\section{Results and discussion}

\subsection{Characterization of carbon fuels}

XRD results of three carbon fuels are presented in Fig. 2. In the GC profile, the main peak was at $2 \theta=26.5^{\circ}$, corresponding to (002) graphitic reflection, indicates GC has highly ordered crystalline structure. For BC pattern, the less intensive peak (002) around $24^{\circ}$ and the sharp (100) peak at $44^{\circ}$ can be ascribed to some amount of graphitized structure. Compared to $\mathrm{BC}$ and $\mathrm{GC}$ patterns, $\mathrm{AC}$ has the board diffraction peak (002) with another weak and board peak (100) manifesting that it has more amorphous carbon structure. To our knowledge, the crystallinity degree of carbon is crucial parameter for carbon electrochemical reactivity. With lower extent of graphitization, the disordered carbon is a more active fuel for DCFC performance. 


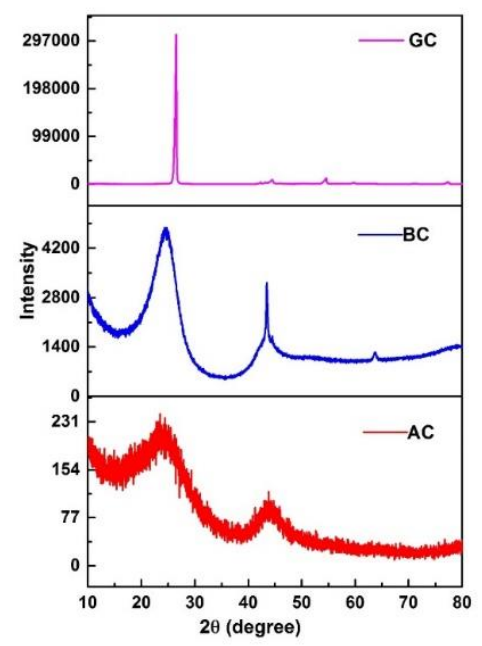

Fig. 2. XRD patterns of three carbon fuels: AC, BC and GC.

Particle size distribution and Nitrogen adsorption isotherms of three samples before and after electrochemical tests are given in Fig. 3. The surface and structural properties of the carbon fuels are summarized in Table 1. As shown in Fig. 3 (a), the average particle size for raw $\mathrm{AC}, \mathrm{BC}$ and $\mathrm{GC}$ is 104,16 , and $12 \mu \mathrm{m}$, respectively. It is clear that particle number concentration and size distribution show GC is more homogeneous than the other two. After the electrochemical reactivity, three carbon residues wash and dry for wiping off adherent carbonate and other ash content. Interestingly, the size distributions of $\mathrm{BC}$ and $\mathrm{GC}$ are increasingly shifted towards higher values, while the peak of AC residue is barely budged, which is in line with SEM of carbon samples, as shown in Fig. 4. That means the disordered AC with more edge sites, defects and oxygen-containing groups are readily to generate more active sites for the carbon oxidation and thus may not be benefit for physical adsorption with carbonate. According to the data in table 1, after test the higher BET surface of $\mathrm{AC}$ and $\mathrm{BC}$ with higher porosities decrease from $593.91 \mathrm{~m}^{2} \mathrm{~g}^{-1}$ to $212.41 \mathrm{~m}^{2} \mathrm{~g}^{-1}$ and from $219.64 \mathrm{~m}^{2} \mathrm{~g}^{-1}$ to $74.33 \mathrm{~m}^{2} \mathrm{~g}^{-1}$, respectively, associated with pore volumes. In contrast, after measurement 
the BET surface of GC increases sharply from $10.21 \mathrm{~m}^{2} \mathrm{~g}^{-1}$ to $85.85 \mathrm{~m}^{2} \mathrm{~g}^{-1}$. Furthermore, an amount of mesoporous and macroporous structure can be detected distinctly in GC residues, but seem to disappear in raw GC. These dramatic changes in GC residues are mainly caused by large amount of wrapped carbonate aggregation, which is difficult to desorb by washing from carbon surfaces.

\section{Table 1}

Surface and structural properties of the carbon fuels. (\#: the residues after test).

\begin{tabular}{llllllc}
\hline Carbon fuel & AC & AC\# & BC & BC\# & GC & GC\# \\
\hline Particle size $(\mu \mathrm{m})$ & 104 & 111 & 16 & 131 & 12 & 250 \\
BET Surface Area $\left(\mathrm{m}^{2} / \mathrm{g}\right)$ & 593.91 & 212.41 & 219.64 & 74.33 & 10.21 & 85.85 \\
Micropore Area $\left(\mathrm{m}^{2} / \mathrm{g}\right)$ & 268.67 & 90.90 & 60.43 & 31.57 & - & - \\
Total Pore Volume $\left(\mathrm{cm}^{3} / \mathrm{g}\right)$ & 0.49 & 0.13 & 0.24 & 0.048 & 0.021 & 0.078 \\
Micropore Volume $\left(\mathrm{cm}^{3} / \mathrm{g}\right)$ & 0.13 & 0.044 & 0.029 & 0.015 & -0.0021 & -0.0041 \\
\hline
\end{tabular}

(a)

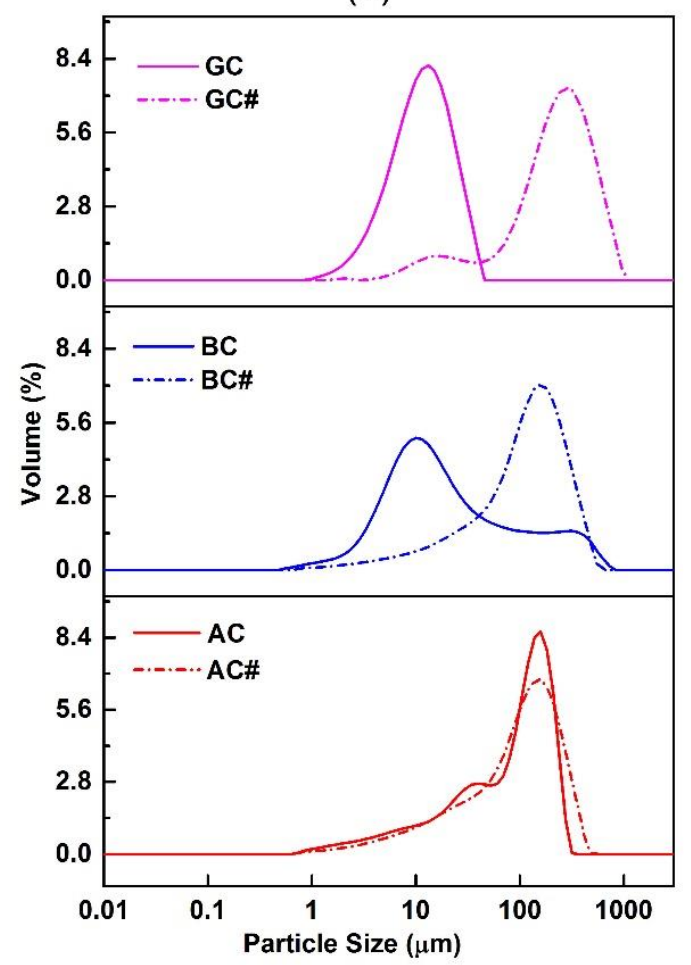

(b)

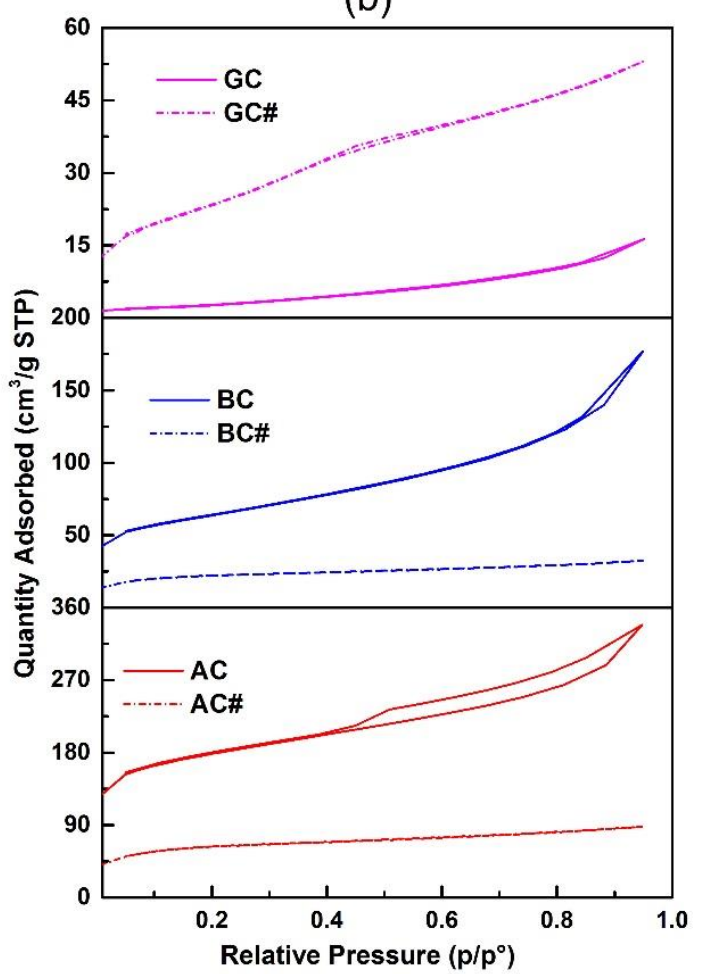

Fig. 3. (a) Particle Size Distribution and (b) Nitrogen adsorption isotherms for carbons before and 
after electrochemical measurement. (\#: the residues after test).

As for Fig. 3 (b), all of six samples display type IV isotherms but with discriminative hysteresis loops. AC curves rise rapidly with a wide hysteresis loop from the intermediate zone, indicating it's typical of mesoporous and macroporous materials. Unlike AC, a loop for BC merely exists at the end of curve, as well as GC with small amounts of mesopores and macropores. However, quantity adsorption of $\mathrm{AC}$ and $\mathrm{BC}$ residues reduce dramatically as the decrease of mesoporous and macroporous structure, which can be deduced from subtraction between total pore volume and micropore volume in Table 1 . In contrast, the quantity adsorption curves of GC residues increase and present a hysteresis loop in intermediate region, indicating the formation of mesoporous and macroporous structure due to the absorption of remaining carbonate, which is also can be observed in SEM.
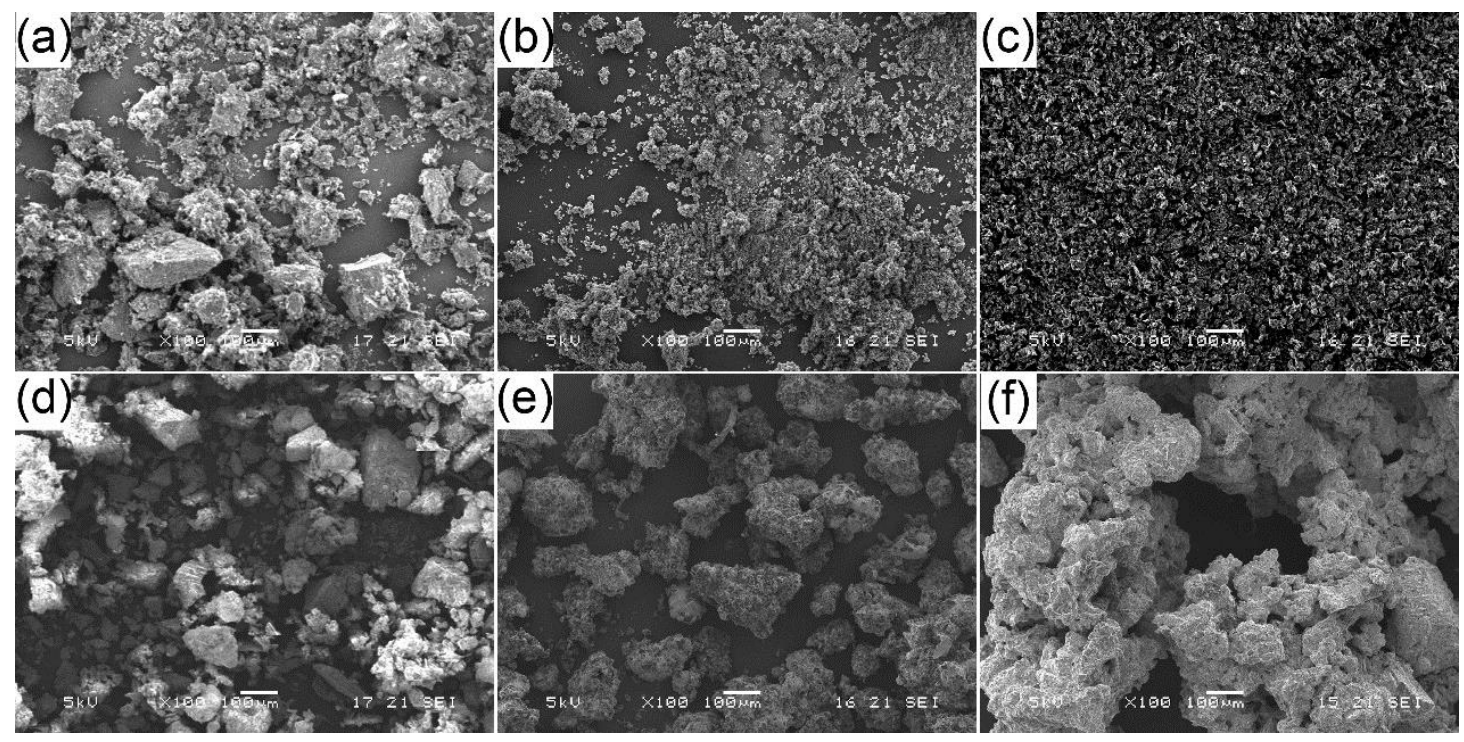

Fig. 4. Scanning electron microscope images of carbon samples: (a) AC; (b) BC; (c) GC; (d) AC\#; (e) BC\#; (f) GC\#. (\# represents samples after electrochemical measurement.)

TG analysis is an effective way to investigate the carbon oxidation process and 
chemical thermal stability. The TGA profiles of samples under air in the temperature range of $20-900{ }^{\circ} \mathrm{C}$ are presented in Fig. 5(a). Among three samples, the total loss of $\mathrm{AC}, \mathrm{BC}$ and $\mathrm{GC}$ is $90.6 \%, 100 \%$ and $99.2 \%$, respectively. That implies the $\mathrm{AC}$ shows the highest ash content with $9.4 \%$ of the total weight, which may contain inorganic component with catalytic property improving the carbon oxidizing reactivity. For AC samples, a significant weight loss before $100{ }^{\circ} \mathrm{C}$ is attributed to the release of the moisture content. The onset of oxidation of carbonaceous materials around $410{ }^{\circ} \mathrm{C}$ is much lower than that of $\mathrm{BC}$ (approximately $540{ }^{\circ} \mathrm{C}$ ) and $\mathrm{GC}$ (approximately $640{ }^{\circ} \mathrm{C}$ ). It is clear that The AC samples exhibit higher thermal reactivity due to the decomposition of surface functional groups. The presence of oxygen-containing groups thereby decrease the thermal stability of $\mathrm{AC}$ to a large extent, according to previous researches $[17,18]$. The intensive thermal stability of GC can be related to the highly crystalline structure, as described in XRD analysis. Thus as expected, the thermal stability of three carbons in air increase in the rank $\mathrm{AC}<\mathrm{BC}<\mathrm{GC}$.

The TGA curves of $\mathrm{AC}, \mathrm{BC}$ and $\mathrm{GC}$ fuels in $\mathrm{N}_{2}$ purge gas are displayed in Fig. 5(b). GC samples keep thermal stability until the ending temperature $\left(900{ }^{\circ} \mathrm{C}\right)$ with slight decomposition starting around $700{ }^{\circ} \mathrm{C}$. However, an apparent weigh loss of AC samples occurs before $100{ }^{\circ} \mathrm{C}$ due to release of water. Then the continuous decline of total weight during the thermal treatment can be suggested to decomposition of volatiles, tar and carbon-oxygen functional groups. 

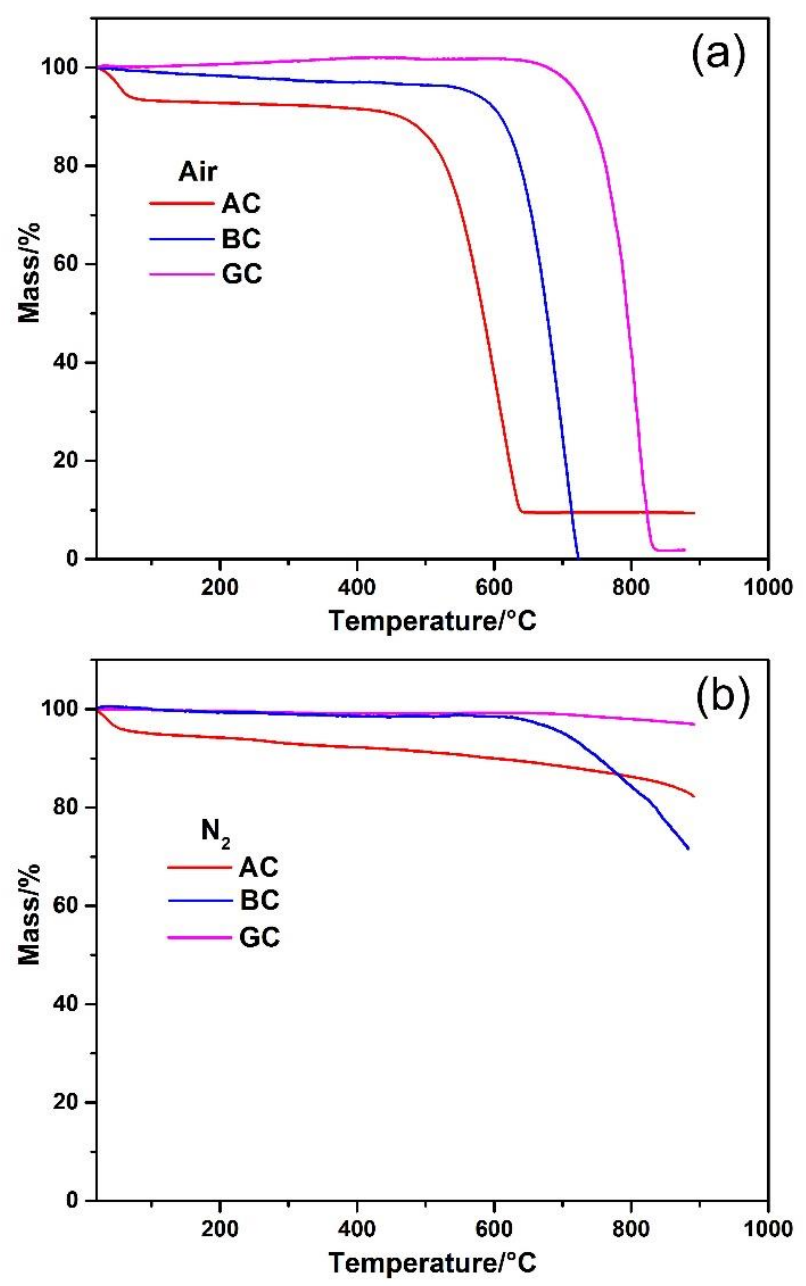

Fig. 5. TG analysis of three carbon fuels under different atmosphere: (a) Air, (b) $\mathrm{N}_{2}$.

\subsection{Electrochemical performance of HDCDC}

\subsubsection{A comparison for electrochemical results of three carbon sources}

The summarized electrochemical results of $\mathrm{AC}, \mathrm{BC}$ and $\mathrm{GC}$ samples in different atmospheres at $650-800{ }^{\circ} \mathrm{C}$ are given below in table 2 . It can be seen that under three purge gas OCV (open circuit voltage) values increase as the temperature increases, associated with the highest values in $\mathrm{N}_{2}$ gas. Although carbon electrochemical oxidation should prevail in the anode chamber in $\mathrm{HDCFC}, \mathrm{OCV}$ values of $\mathrm{AC}$ in $\mathrm{H}_{2}$ is in good agreement with the theoretical values calculated from Nernst equation with $\mathrm{H}_{2}$ feedstock with a higher MPD (maximum power density) of $938 \mathrm{~mW} \mathrm{~cm}{ }^{-2}$ at $800^{\circ} \mathrm{C}$ 
indicating the incorporation of $\mathrm{H}_{2}$ feedstock enables $\mathrm{H}_{2}$ electrochemical oxidation being the dominant electrochemical reaction. Altering $\mathrm{N}_{2}$, the observed MPD of AC in $\mathrm{N}_{2}$ is $535 \mathrm{~mW} \mathrm{~cm}^{-2}$ at $800^{\circ} \mathrm{C}$, which is much higher than that in other DCFCs. Apparently, the MPD and MCD (maximum current density) show much lower values at $650{ }^{\circ} \mathrm{C}$. The significant drop can be attributed to the lower reaction kinetics of produced $\mathrm{CO}$ resulting from the reverse Boudouard equilibrium (Eq. 1) in a lower temperature $\left(<700{ }^{\circ} \mathrm{C}\right)[19]$. It should be noted that the addition of $\mathrm{CO}_{2}$ is able to promote reverse Boudouard reaction[20], resulting in higher power output due to the dominating $\mathrm{CO}$ electro-oxidation by Eq. 2. However, Eq.1 is the strongly temperature dependent evidenced by AC sampled with a higher MPD of $49 \mathrm{~mW} \mathrm{~cm}^{-2}$ in $\mathrm{N}_{2}$ flow than that of $21 \mathrm{~mW} \mathrm{~cm}^{-2}$ in $\mathrm{CO}_{2}$ flow at $650{ }^{\circ} \mathrm{C}$. In most investigated DCFC types including SOFCtype[21], MCFC-type[8] and HDCFC-type[22], the electrochemical performance of the DCFC appears to be limited by $\mathrm{CO}$ concentration primarily derived from the reverse Boudouard reaction in the anode compartment.

$$
\begin{aligned}
& \mathrm{C}+\mathrm{CO}_{2} \leftrightarrow 2 \mathrm{CO} \\
& \mathrm{CO}+\mathrm{O}^{2-} \rightarrow \mathrm{CO}_{2}+2 \mathrm{e}^{-}
\end{aligned}
$$

In all cases, AC presents the best electrochemical activity illustrated by its OCP, MCD and MPD. while GC shows the lowest electrochemical reactivity in different atmospheres and at different temperatures. It is observed that the variation of OCV values of GC seems to be slight as the temperature descending. The presence of the $\mathrm{CO}_{2}$ flow has no significant influence on the performance of graphite fuel. Especially, the MPD of $75 \mathrm{~mW} \mathrm{~cm}^{-2}$ in $\mathrm{N}_{2}$ is even higher than that of $59 \mathrm{~mW} \mathrm{~cm}^{-2}$ in $\mathrm{CO}_{2}$ at $750{ }^{\circ} \mathrm{C}$. 
The tabular results show the order of three carbon fuels in HDCFC performance is $\mathrm{AC}>\mathrm{BC}>\mathrm{GC}$, as expected in previous researches in $\mathrm{DCFC}[14,18]$. There suggests to be two main factors on the electrochemical activity together with the aforementioned characterization of carbon fuels. It has been proved that the surface oxygen groups are favor to complex chemical reactions (producing more $\mathrm{H}_{2}, \mathrm{CH}_{4}$ and $\mathrm{CO}$ ), enhancing the labile carbonaceous structure activity in carbon-carbonate slurry[16, 23] . XRD results of AC with more disordered structure, continuous weight loss in TGA and high surface area, indicates AC samples associated with higher loading of reactive surface oxygencontaining groups generate larger current density at fixed potentials. Compared to AC, BC samples with small amounts of graphite structure show lower reactivity in electrochemical process. The lowest electrochemical performance for GC is linked to its strongly stable graphite structure and high thermal stability. In addition, considering the viscosity of the molten carbonate, the mass transfer through the active electrochemical sites is affected by the carbon textural properties, especially the fraction of porosity $[4,24]$. AC fuels with more mesoporous and macroporous structure enhance the transport of carbonate media through the carbon skeleton and thus improve the active reaction sites. $\mathrm{BC}$ and $\mathrm{GC}$ feedstocks dominated by microporous or nonporous structure are not accessible to molten carbonate result in lower current density.

Table 2

Electrochemical data of $\mathrm{AC}, \mathrm{BC}$ and $\mathrm{GC}$ at $650-800{ }^{\circ} \mathrm{C}$.

\begin{tabular}{|c|c|c|c|c|c|c|c|c|}
\hline \multicolumn{3}{|c|}{$\mathrm{AC}$} & \multicolumn{3}{|c|}{$\mathrm{BC}$} & \multicolumn{3}{|c|}{ GC } \\
\hline $\begin{array}{c}\text { OCV } \\
\text { (V) }\end{array}$ & $\begin{array}{c}\mathrm{MCD} \\
(\mathrm{mA} \\
\left.\mathrm{cm}^{-2}\right)\end{array}$ & $\begin{array}{c}\text { MPD } \\
(\mathrm{mW} \\
\left.\mathrm{cm}^{-2}\right)\end{array}$ & $\begin{array}{c}\mathrm{OCV} \\
\text { (V) }\end{array}$ & $\begin{array}{c}\mathrm{MCD} \\
(\mathrm{mA} \\
\left.\mathrm{cm}^{-2}\right)\end{array}$ & $\begin{array}{l}\text { MPD } \\
(\mathrm{mW} \\
\left.\mathrm{cm}^{-2}\right)\end{array}$ & $\begin{array}{c}\text { OCV } \\
\text { (V) }\end{array}$ & $\begin{array}{l}\mathrm{MCD} \\
(\mathrm{mA} \\
\left.\mathrm{cm}^{-2}\right)\end{array}$ & $\begin{array}{c}\text { MPD } \\
(\mathrm{mW} \\
\left.\mathrm{cm}^{-2}\right)\end{array}$ \\
\hline
\end{tabular}




\begin{tabular}{lccccccccc}
\hline $\mathrm{H}_{2}$ & & & & & & & & & \\
$650{ }^{\circ} \mathrm{C}$ & 1.067 & 304 & 148 & 1.066 & 241 & 123 & 1.059 & $266-$ & 121 \\
$700{ }^{\circ} \mathrm{C}$ & 1.085 & 749 & 349 & 1.072 & 562 & 270 & 1.065 & 600 & 303 \\
$750{ }^{\circ} \mathrm{C}$ & 1.091 & 1419 & 636 & 1.073 & 928 & 470 & 1.065 & 1134 & 600 \\
$800{ }^{\circ} \mathrm{C}$ & 1.098 & 1896 & 938 & 1.094 & 1847 & 948 & 1.065 & 1842 & 949 \\
$\mathrm{~N}_{2}$ & & & & & & & & & \\
$650{ }^{\circ} \mathrm{C}$ & 0.934 & 87 & 49 & 0.62 & 30 & 13 & 0.703 & 36 & 12 \\
$700^{\circ} \mathrm{C}$ & 1.07 & 109 & 79 & 0.76 & 48 & 21 & 0.894 & 57 & 28 \\
$750{ }^{\circ} \mathrm{C}$ & 1.09 & 313 & 210 & 1.013 & 168 & 100 & 0.957 & 123 & 75 \\
$800{ }^{\circ} \mathrm{C}$ & 1.106 & 945 & 535 & 1.097 & 395 & 224 & 0.959 & 259 & 154 \\
$\mathrm{CO}_{2}$ & & & & & & & & & \\
$650{ }^{\circ} \mathrm{C}$ & 0.865 & 35 & 21 & 0.57 & 18 & 11 & 0.599 & 21 & 9 \\
$700{ }^{\circ} \mathrm{C}$ & 0.964 & 252 & 155 & 0.774 & 85 & 38 & 0.778 & 46 & 28 \\
$750{ }^{\circ} \mathrm{C}$ & 0.974 & 531 & 326 & 0.911 & 293 & 147 & 0.828 & 97 & 59 \\
$800{ }^{\circ} \mathrm{C}$ & 0.974 & 872 & 489 & 0.946 & 783 & 380 & 0.829 & 291 & 170 \\
\hline $\mathrm{OCV}$ &
\end{tabular}

OCV: Open circuit voltage. MCD: Maximum current density. MPD: Maximum power density.

Fig.6 compares electrochemical performance of three carbon fuels in $\mathrm{CO}_{2}$ flow at $750{ }^{\circ} \mathrm{C}$. The maximum power densities measured for AC, BC and GC are 326, 147 and $59 \mathrm{~mW} \mathrm{~cm}^{-2}$, respectively. Unlike the I-V-P curve of AC samples, BC and GC curves present unsteady bounce around the maximum current density, as the current density increases. Nyquist plots of the impedance data obtained at OCV is shown in Fig. 6(b). The ohmic losses $\left(R_{o}\right)$ correspond to the high-frequency real-axis intercept and the polarization resistances $\left(R_{P}\right)$ are acquired by subtracting between the total resistances (low-frequency intercepts at real-axis) and the ohmic resistances. The ohmic resistances for AC, BC and GC are $0.345,0.445$ and $0.347 \Omega \mathrm{cm}^{2}$. Obviously, it can be seen that the polarization resistance plays a more dominated role in HDCFC performance. Although GC shows the lowest $R_{o}$, almost as the same as AC, due to its highest electrical conductivity of three carbons, the largest polarization resistance gives rise to the poorest the performance in HDCFC. 

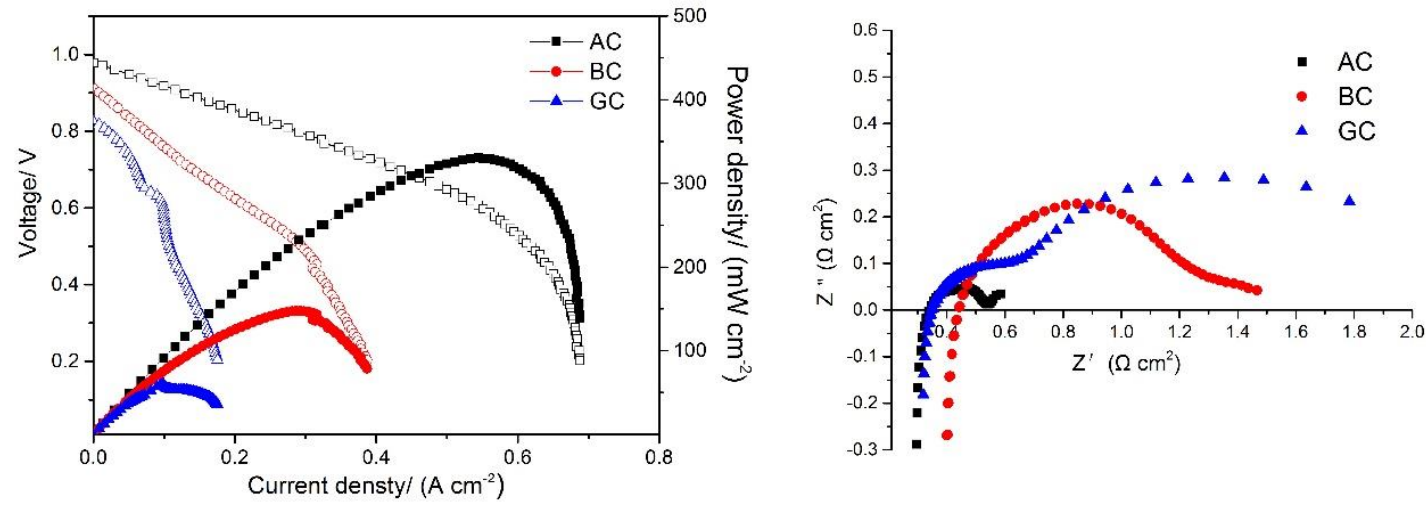

Fig. 6. (a) Current-voltage characteristics of three carbon fuels measured in $\mathrm{CO}_{2}$ purge gas at $750{ }^{\circ} \mathrm{C}$, (b) Impedance spectra of three carbon fuels measured in $\mathrm{CO}_{2}$ purge gas at $750{ }^{\circ} \mathrm{C}$.

\subsubsection{The explanation of abrupt changes in I-V-P curves}

As disscussed above, AC demonstrates the best performance. To further investigate the effect of the carbon type, temperature and atmosphere on the evaluation of chemical and electrochemical mechisms in the anode, the representative I-V-P curves of AC acquired in $\mathrm{CO}_{2}$ at $700{ }^{\circ} \mathrm{C}$ are shown in Fig.7. The representative I-V curve shows the stable linear region from $\mathrm{OCV}$ to $252 \mathrm{~mA} \mathrm{~cm}^{-2}$ (maximum current density), implying the anodic electrochemical process is dominated by ohmic resistance polarization in lower current density. As the current density increased, the potential followed by the sharp drop after the red dash line mark can be ascribed to concentration polarization, resulting from mass transfer limitation due to the electrochemical oxidation of $\mathrm{CO}$ as shown in the severe distortion of I-P curve on the right of the red dash line. However, the abrupt change in I-V-P plots are found in three carbon types with different temperatures and purge gases, as shown in Fig. 8. The shape of abrupt change doesn't seem to match the sharp drop in Fig.6, despite the phenomenon occurs at the maximum current density. However, the similarity is unlikely to result from mass transfer 
limitation due to the electrochemical oxidation of CO. It should be noted that these changes in the plot are easily observed at lower temperatures and in rich inert atmosphere, related to a change in reaction mechanism or the transformation in RDS (rate determining step)[20, 25, 26]. Indeed, these changes appears at discriminative locations due to various experimental conditions, including the ratio of carboncarbonate, the temperature and the anode structure.

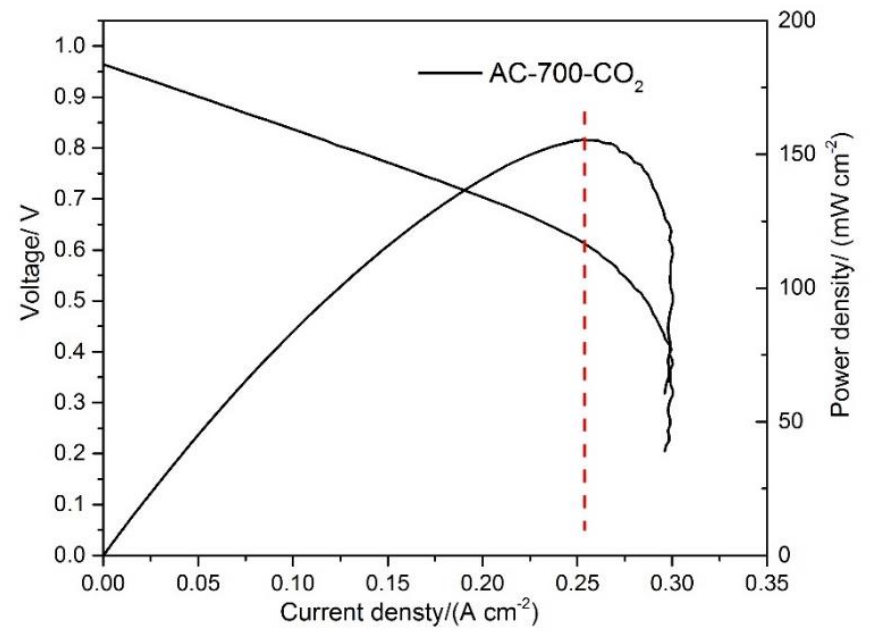

Fig. 7. Representative I -V-P curves of $\mathrm{AC}$ measured in $\mathrm{CO}_{2}$ at $700{ }^{\circ} \mathrm{C}$. 

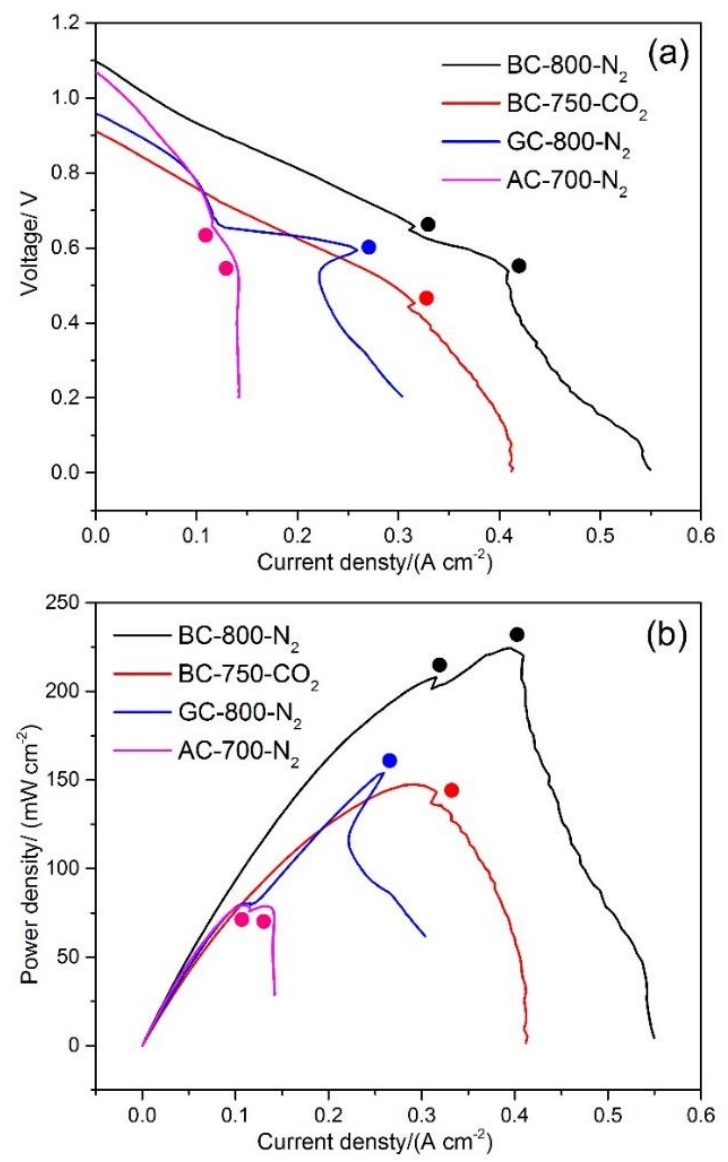

Fig. 8. I-V an I-P curves with abnormal changes (marked as filled circle) in different purge gases and at different temperatures.

\subsubsection{The effect of the operating temperature and purge gas}

As EIS analysis and the model circuit fitting reported for HDCFC[20, 27, 28], the polarization arc can be interpreted in three processes. The high frequency impedance arc was attributed to charge transfer resistance at the anode/ electrolyte interface; the intermediate frequency arc was ascribed to the electrode reaction, including the complex chemical and electrochemical process in the anode and oxygen reduction in the cathode. The low frequency arc is suggested to be not only limited by gas diffusion, but also related to mass transfer, such as flooded carbon- carbonate slurry and bubble evolution in the anode chamber [29]. In terms of the effects of temperature, EIS data is 
employed to investigate the anode process in $\mathrm{CO}_{2}$ and $\mathrm{N}_{2}$ flow. Representative EIS curves of $\mathrm{AC}$ fuels with $\mathrm{CO}_{2}$ flow in different temperatures are shown in Fig.9 (a). It can be found that $R_{o}$ is expected to decrease with increasing temperature due to oxide ion of electrolyte (YSZ) temperature dependent, while $R_{P}$ decreases greatly as the elevated temperature associated with various parameters, such as the enhanced reaction kinetics, the decreasing viscosity of the molten carbonate. The trend of EIS curve shapes are similar between 700 and $800{ }^{\circ} \mathrm{C}$ except for $650^{\circ} \mathrm{C}$. Fig. 9 (b) presents Nyquist plots of the impedance data obtained for AC fuels in $\mathrm{N}_{2}$ flow at different temperatures. The huge difference suggests that there is significantly larger $R_{P}$ instead of $\mathrm{N}_{2}$ flow, dominated by mass transfer process (the low frequency), resulting in poor performance in HDCFC. These means that the presence of $\mathrm{CO}_{2}\left(>700{ }^{\circ} \mathrm{C}\right)$ in the anode chamber as an essential intermediate not only catalyzes the carbon oxidation process, but also reduces mass transfer contribution. Similarly, the shapes in $\mathrm{N}_{2}$ are parallel in the temperature of $700-800{ }^{\circ} \mathrm{C}$. Additionally, the similar shapes are obtained in $\mathrm{CO}_{2}$ and $\mathrm{N}_{2}$ at $650{ }^{\circ} \mathrm{C}$. Additionally, the similar shapes can be observed in $\mathrm{CO}_{2}$ and $\mathrm{N}_{2}$ at $650{ }^{\circ} \mathrm{C}$, implying the incorporation of purge gas has little effect on electrochemical process. Compared to the presence of $\mathrm{N}_{2}$ flow, both $R_{o}$ and $R_{P}$ increase in presence of $\mathrm{CO}_{2}$ flow at $650{ }^{\circ} \mathrm{C}$. According to the summarized electrochemical data in Table 2, the increase of $R_{o}$ and $R_{P}$ in $\mathrm{CO}_{2}$ flow suggest superior performance can be obtained in $\mathrm{N}_{2}$ than in $\mathrm{CO}_{2}$, mainly due to poor kinetic reaction of reverse Boudouard reaction. In this condition, the introducing $\mathrm{CO}_{2}$ is unfavorable to the cell performance because of lower OCV deduced from Nernst equation. 

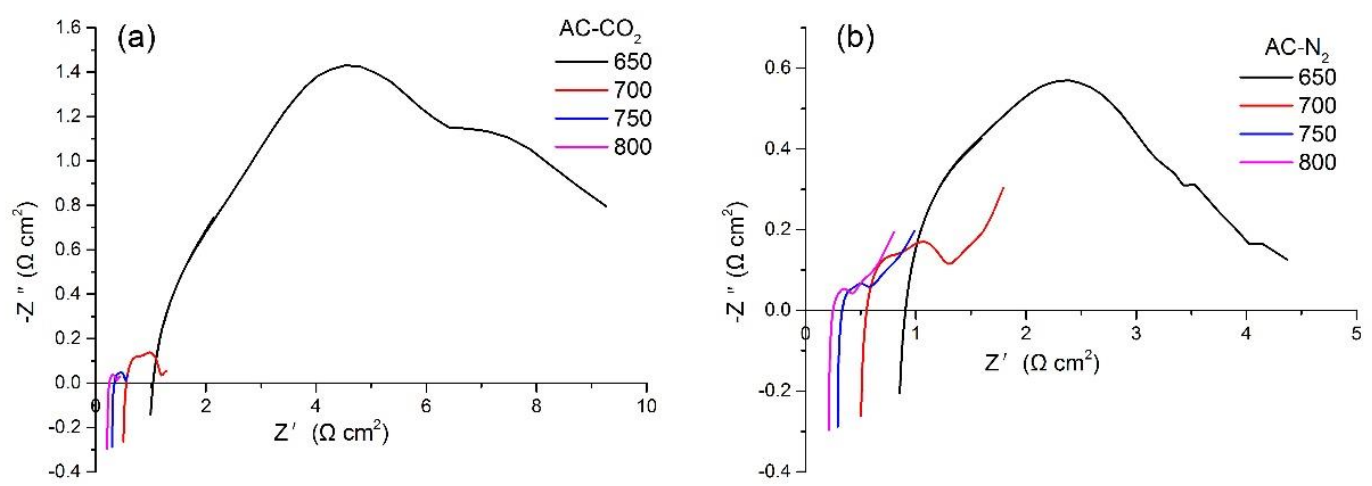

Fig.9. Nyquist plots of the impedance data obtained for AC fuels at different temperatures. (a) in $\mathrm{CO}_{2}$ flow; (b) $\mathrm{N}_{2}$ flow

\section{Conclusion}

Three types of commercial carbon fuels including activated carbon, carbon black and graphite have been investigated in hybrid carbon fuel cells (HDCFC). The order for the electrochemical performance of three types of carbon fuels are activated carbon > carbon black > graphite.

It has been found that activated carbon with characteristics of disorder structure, higher surface area and lower thermal stability promoting more $\mathrm{CO}$ formation result in the best cell performance among three carbon fuels. In addition, more mesoporous and macroporous structure in AC samples enhance the transport of carbonate media through the carbon skeleton and lead to more active reaction sites. Even though the OCV values are not strongly temperature dependent, the stable structure of GC is not in favor of reverse Boudouard reaction producing $\mathrm{CO}$ products and microporous or nonporous structure in GC go against the sufficient contact between carbon and molten carbonate.

Based on electrochemical performance measurement, the addition of $\mathrm{H}_{2}$ flowing 
hiding carbon related electrochemical and chemical reaction, but altering the $\mathrm{N}_{2}$ and $\mathrm{CO}_{2}$ flowing, the dominating $\mathrm{CO}$ electrochemical oxidation account for the improved power output. The introducing $\mathrm{CO}_{2}$ purge gas as a crucial intermediate enhances the anodic reaction process at $700-800{ }^{\circ} \mathrm{C}$, even though the obtained $\mathrm{OCV}$ is lower than in $\mathrm{N}_{2}$ flow. However, the worse performance in $\mathrm{CO}_{2}$ flow at $650{ }^{\circ} \mathrm{C}$ indicates $\mathrm{CO}_{2}$ purge gas plays a negative role in electrochemical performance due to the unfavorable reverse Boudouard reaction in lower temperatures.

The acquired EIS results shows the similarity trend in $\mathrm{N}_{2}$ and $\mathrm{CO}_{2}$ at $650{ }^{\circ} \mathrm{C}$ due to sluggish kinetics of Boundouard reaction and the polarization resistance plays a dominated role in the cell performance. Furthermore, a slope abrupt change in I-V-P curve is ascribed to a change in reaction mechanism or certain special reaction.

\section{Acknowledgement}

The authors acknowledge the financial support of the Royal Society of Edinburgh for a RSE BP Hutton Prize in Energy Innovation. The authors also would like to thank Haoliang Tao, Jun Gao, and Juan Liu for their help in the cell fabrication process.

\section{References}

[1] Giddey S, Badwal SPS, Kulkarni A, Munnings C. A comprehensive review of direct carbon fuel cell technology. Progress in Energy and Combustion Science. 2012;38:360-99.

[2] Gur TM. Critical review of carbon conversion in "carbon fuel cells". Chem Rev. 2013;113:6179-206.

[3] Rady AC, Giddey S, Kulkarni A, Badwal SPS, Bhattacharya S. Catalytic gasification of carbon in a direct carbon fuel cell. Fuel. 2016;180:270-7.

[4] Elleuch A, Halouani K, Li YD. Investigation of chemical and electrochemical reactions mechanisms in a direct carbon fuel cell using olive wood charcoal as sustainable fuel. Journal of Power Sources. 2015;281:350-61.

[5] W.W. Jacques, US patent no. 555,551 (1896).

[6] Patton EM, Zecevic S, Parharni P. Direct carbon fuel cell with stable molten hydroxide catholyte. Proceedings of the 4th International Conference on Fuel Cell Science, Engineering, and Technology, Pts A and B. 2006:463-5. 
[7] Zecevic S, Patton EM, Parhami P. Carbon-air fuel cell without a reforming process. Carbon. 2004;42:1983-93.

[8] Cherepy NJ, Krueger R, Fiet KJ, Jankowski AF, Cooper JF. Direct conversion of carbon fuels in a molten carbonate fuel cell. Journal of the Electrochemical Society. 2005;152:A80-A7.

[9] Gur TM, Homel M, Virkar AV. High performance solid oxide fuel cell operating on dry gasified coal. Journal of Power Sources. 2010;195:1085-90.

[10] Cai WZ, Zhou Q, Xie YM, Liu J. A facile method of preparing Fe-loaded activated carbon fuel for direct carbon solid oxide fuel cells. Fuel. 2015;159:887-93.

[11] Nabae Y, Pointon KD, Irvine JTS. Electrochemical oxidation of solid carbon in hybrid DCFC with solid oxide and molten carbonate binary electrolyte. Energ Environ Sci. 2008;1:148-55.

[12] Jiang CRM, J. J. Bonaccorso, A. D. Irvine, J. T. S. Demonstration of high power, direct conversion of waste-derived carbon in a hybrid direct carbon fuel cell. Energ Environ Sci. 2012;5:6973-80.

[13] Jiang CR, Ma JJ, Arenillas A, Irvine JTS. Hybrid Direct Carbon Fuel Cells with Different Types of Mineral Coal. Solid Oxide Fuel Cells 13 (Sofc-Xiii). 2013;57:3013-21.

[14] Xu XY, Zhou W, Liang FL, Zhu ZH. A comparative study of different carbon fuels in an electrolytesupported hybrid direct carbon fuel cell. Appl Energ. 2013;108:402-9.

[15] Xu XY, Zhou W, Liang FL, Zhu ZH. Optimization of a direct carbon fuel cell for operation below 700 degrees C. International Journal of Hydrogen Energy. 2013;38:5367-74.

[16] Deleebeeck L, Arenillas A, Menendez JA, Hansen KK. Hybrid direct carbon fuel cell anode processes investigated using a 3-electrode half-cell setup. International Journal of Hydrogen Energy. 2015;40:1945-58.

[17] Li X, Zhu ZH, Chen JL, De Marco R, Dicks A, Bradley J, et al. Surface modification of carbon fuels for direct carbon fuel cells. Journal of Power Sources. 2009;186:1-9.

[18] Li X, Zhu ZH, De Marco R, Dicks A, Bradley J, Liu SM, et al. Factors That Determine the Performance of Carbon Fuels in the Direct Carbon Fuel Cell. Ind Eng Chem Res. 2008;47:9670-7.

[19] Chen CC, Maruyama T, Hsieh PH, Selman JR. The reverse Boudouard reaction in Direct Carbon Fuel Cells. Batteries and Energy Technology (General) - 217th Ecs Meeting. 2010;28:227-39.

[20] Deleebeeck L, Hansen KK. HDCFC Performance as a Function of Anode Atmosphere (N-2-CO2). Journal of the Electrochemical Society. 2014;161:F33-F46.

[21] Gur TM. Mechanistic Modes for Solid Carbon Conversion in High Temperature Fuel Cells. Journal of the Electrochemical Society. 2010;157:B751-B9.

[22] Chien AC, Arenillas A, Jiang CR, Irvine JTS. Performance of Direct Carbon Fuel Cells Operated on Coal and Effect of Operation Mode. Journal of the Electrochemical Society. 2014;161:F588-F93.

[23] Wang CQ, Liu J, Zeng J, Yin JL, Wang GL, Cao DX. Significant improvement of electrooxidation performance of carbon in molten carbonates by the introduction of transition metal oxides. Journal of Power Sources. 2013;233:244-51.

[24] Jiang Y, Virkar AV. Fuel composition and diluent effect on gas transport and performance of anodesupported SOFCs. Journal of the Electrochemical Society. 2003;150:A942-A51.

[25] Cooper JF, Selman JR. Analysis of the carbon anode in direct carbon conversion fuel cells. International Journal of Hydrogen Energy. 2012;37:19319-28.

[26] Siengchum T, Guzman F, Chuang SSC. Analysis of gas products from direct utilization of carbon in a solid oxide fuel cell. Journal of Power Sources. 2012;213:375-81.

[27] Jiang CR, Irvine JTS. Catalysis and oxidation of carbon in a hybrid direct carbon fuel cell. Journal of Power Sources. 2011;196:7318-22. 
[28] Deleebeeck L, Ippolito D, Hansen KK. Enhancing Hybrid Direct Carbon Fuel Cell anode performance using Ag2O. Electrochimica Acta. 2015;152:222-39.

[29] Kim M, Kim K, Hwang M, Kim K, Song J. Evaluation of bubble suspension behavior in electrolyte melts. Korean J Chem Eng. 2014;31:201-10. 